Research article

\title{
Microparticle-induced release of B-lymphocyte regulators by rheumatoid synoviocytes
}

\author{
Laurent Messer ${ }^{1,2}$, Ghada Alsaleh1,2, Jean-Marie Freyssinet ${ }^{3,4}$, Fatiha Zobairi3,4, Isabelle Leray ${ }^{1,2}$, \\ Jacques-Eric Gottenberg ${ }^{1,2}$, Jean Sibilia1,2, Florence Toti-Orfanoudakis ${ }^{3,4}$ and \\ Dominique Wachsmann ${ }^{1,2}$
}

\begin{abstract}
1'Laboratoire Physiopathologie des Arthrites, Université de Strasbourg, UFR Sciences Pharmaceutiques, 74 route du Rhin, Illkirch 67401, France 2Département de Rhumatologie, Hôpitaux Universitaires de Strasbourg, Avenue Molière, Strasbourg Hautepierre 67200, France

3Laboratoire de Biologie Cellulaire et Vasculaire, Faculté de Médecine, 4 rue Kirschleger, Strasbourg 67085, France

${ }^{4}$ Inserm U770 Hôpital Bicêtre (AP-HP), 78 rue du Général Leclerc, Le Kremlin-Bicêtre 94275, France
\end{abstract}

Corresponding author: Dominique Wachsmann, dominique.wachsmann@pharma.u-strasbg.fr

Received: 23 Feb 2009 Accepted: 16 Mar 2009 Published: 16 Mar 2009

Arthritis Research \& Therapy 2009, 11:R40 (doi:10.1186/ar2648)

This article is online at: http://arthritis-research.com/content/11/2/R40

(C) 2009 Messer et al.; licensee BioMed Central Ltd.

This is an open access article distributed under the terms of the Creative Commons Attribution License (http://creativecommons.org/licenses/by/2.0), which permits unrestricted use, distribution, and reproduction in any medium, provided the original work is properly cited.

\begin{abstract}
Introduction In the present study, we investigated the ability of microparticles isolated from synovial fluids from patients with rheumatoid arthritis or osteoarthritis to induce the synthesis and release of key cytokines of $B$-lymphocyte modulation such as $B$ cell-activating factor, thymic stroma lymphopoietin, and secretory leukocyte protease inhibitor by rheumatoid fibroblastlike synoviocytes.
\end{abstract}

Methods Microparticles were analyzed in synovial fluids from patients with rheumatoid arthritis, osteoarthritis, microcristalline arthritis, and reactive arthritis. In addition, microparticle release after activation from various cell lines (CEM lymphocyte and THP-1 cells) was assessed. Microparticles were isolated by differential centrifugation, and quantitative determinations were carried out by prothrombinase assay after capture on immobilized annexin V. B cell-activating factor, thymic stroma lymphopoietin, and secretory leukocyte protease inhibitor release was evaluated by enzyme-linked immunosorbent assay.

Results Microparticles isolated from synovial fluids obtained from rheumatoid arthritis and osteoarthritis patients or microparticles derived from activated THP-1 cells were able to induce B cell-activating factor, thymic stroma lymphopoietin, and secretory leukocyte protease inhibitor release by rheumatoid arthritis fibroblast-like synoviocytes. Conversely, CEM-lymphocytes-derived microparticles generated by treatment with a combination of PHA, PMA and Adt-D did not promote the release of $B$ cell-activating factor but favored the secretion of thymic stroma lymphopoietin and secretory leukocyte protease inhibitor by rheumatoid arthritis fibrobast-like synoviocytes. However, microparticles isolated from actinomycin D-treated CEM lymphocytes were not able to induce B cell-activating factor, thymic stroma lymphopoietin, or secretory leukocyte protease inhibitor release, indicating that microparticles derived from apoptotic $T$ cells do not function as effectors in B-cell activation.

Conclusions These results demonstrate that microparticles are signalling structures that may act as specific conveyors in the triggered induction and amplification of autoimmunity. This study also indicates that microparticles have differential effects in the crosstalk between B lymphocytes and target cells of autoimmunity regarding the parental cells from which they derive.

ActD: actinomycin D; AID: activation-induced cytidine deaminase; AR: reactive arthritis; BAFF: B cell-activating factor; ELISA: enzyme-linked immunosorbent assay; FCS: fetal calf serum; FLS: fibroblast-like synoviocyte; HBSS: Hanks' balanced saline solution; IFN- $\gamma$ : interferon-gamma; IL: interleukin; LPS: lipopolysaccharide; MC: microcristalline arthritis; MCP: monocyte chemoattractant protein; MMP: matrix metalloproteinase; MP: microparticle; NF-кB: nuclear factor-kappa-B; OA: osteoarthritis; PHA: phytohemagglutinin; PhtdSer Eq: phosphatidylserine equivalents; PMA: phorbolmyristate acetate; PPA: combined PHA, PMA and actinomycin-D; RA: rheumatoid arthritis; SLPI: secretory leukocyte protease inhibitor; TLR: Tolllike receptor; TSLP: thymic stroma lymphopoietin. 


\section{Introduction}

Rheumatoid arthritis (RA) is characterized by a disorganized reaction of the inflammatory and synovial resident cells, fibroblast-like synoviocytes (FLSs), which have a key function in the development of inflammation as well as in tissue destruction $[1,2]$. The activation of the latter may be linked either to the cytokine environment or to interactions between pathogenassociated molecular patterns and pattern-recognition receptors $[3,4]$.

FLSs can also be activated by cell-cell interactions and microparticles (MPs). MPs are submicron structures released from the cell membrane during apoptosis or activation, and they probably play an important role in this intercellular triggering process [5]. MPs expose phosphatidylserine and display surface plasma membrane markers from their parental cells [6]. They are involved in the modulation of key functions, including inflammation, hemostasis, and angiogenesis [7-10]. Elevated MPs circulate in the blood of patients with various inflammatory disorders [11-14]. Berckmans and colleagues [15] demonstrated that, in RA, synovial MPs isolated from arthritic patients induced cytokine release by FLSs. Similarly, Distler and colleagues [16] demonstrated that MPs derived from T cells and monocytes induced the synthesis of various cytokines such as interleukin (IL)-6, IL-8, monocyte chemoattractant protein (MCP)-1 and MCP-2, and metalloproteases such as matrix metalloproteinase (MMP)-1, MMP-3, MMP-9, and MMP-14 by activated FLSs. Thus, MPs appear as multifunctional bioeffectors that could be implicated in the exacerbation of the inflammatory response and cartilage and bone erosion by resident cells in RA.

Previous findings have shown that FLSs participate in the development of the specific immune response by secreting cytokines (SDF-1 and CXCL13) that attracted B cells and allowed the formation of pseudofollicles in the synovial membrane [17-19]. Ohata and colleagues [20] demonstrated that FLSs isolated from RA patients express $B$ cell-activating factor (BAFF) transcripts in response to tumor necrosis factor-alpha and interferon-gamma (IFN- $\gamma$ ). BAFF is known to play a central role in the maturation and survival of $B$ cells as well as in antibody synthesis. However, we recently demonstrated that BAFF secretion by RA FLSs is tightly regulated by a complex network involving innate immunity and cytokines, with positive and negative controls depending on the receptors and pathways triggered. Thus, BAFF synthesis and release by RA FLSs are negatively regulated by Toll-like receptor (TLR) ligands whereas integrin signalling pathways stimulate BAFF secretion by resident cells [21].

It was recently demonstrated that, in the presence of TLRbinding products, epithelial cells from tonsillar crypts released BAFF and IL-10, which stimulated B cells to secrete polyreactive antibodies to multiple microbial determinants. This effect was enhanced by epithelial cell release of thymic stroma lym- phopoietin (TSLP), which induced BAFF production by dendritic cells but could also restrain it by secretory leukocyte protease inhibitor (SLPI) release from activated epithelial cells [22]. In the present study, we investigated the capacity of MPs isolated from synovial fluids of RA and osteoarthritis (OA) patients or derived from various activated cell lines to induce the release of BAFF, TSLP, and SLPI by FLSs isolated from RA patients.

Our data indicated that MPs isolated from synovial fluids of $\mathrm{OA}$ and RA patients were able to induce BAFF, TSLP, and SLPI release by activated FLSs. Since it had been previously demonstrated that most of the MPs present in the synovial fluid of inflamed joints were leukocyte-derived MPs [23], we investigated the ability of MPs isolated from activated CEM lymphocyte and THP-1 cells to induce BAFF, TSLP, and SLPI synthesis by activated RA FLSs.

MPs derived from activated THP-1 cells induced such release as well. In contrast, those derived from activated CEM lymphocytes did not promote the release of BAFF but favored the secretion of TSLP and SLPI by RA FLSs. However, MPs isolated from actinomycin $D$ (ActD)-treated CEM lymphocytes were not able to induce BAFF, TSLP, and SLPI release, indicating that MPs derived from apoptotic $T$ cells do not function as effectors in B-cell activation. Together, these results indicate that MPs represent signalling structures that may act as inducers and amplifying devices of inflammatory and specific immune responses.

\section{Materials and methods Reagents}

Cell culture media (RPMI 1640 and M199), fetal calf serum (FCS), penicillin, streptomycin, and amphotericin B were obtained from Invitrogen Corporation (Cergy-Pontoise, France). Human recombinant IFN- $\gamma$ was purchased from BD Pharmingen (Le Pont-de-Claix, France). Lipopolysaccharide (LPS) from Salmonella abortus equi and type XI collagenase, Hanks' balanced saline solution (HBSS), ActD, phorbolmyristate acetate (PMA), and phytohemagglutinin (PHA) were obtained from Sigma-Aldrich (Saint-Quentin-Fallavier, France). The enzyme immunoassay kits for human BAFF, TSLP, SLPI, IL-6, and IL-8 detection were from R\&D Systems (Lille, France).

\section{Cell culture}

Human FLSs were isolated from RA synovial tissues from different patients at the time of knee joint arthroscopic synovectomy as described previously [24]. The diagnosis conformed to the revised criteria of the American College of Rheumatology [25]. Informed consent was provided in accordance with the Declaration of Helsinki and obtained from all patients. Approval by the ethics committee of the Hopitaux Universitaires de Strasbourg was obtained. FLS cultures were performed as previously described [26]. Experiments were 
performed between the third and ninth passages. During that time, cultures were constituted of a homogeneous population of fibroblastic cells that were negative for CD16 as determined by fluorescence-activated cell sorting analysis. Cell number and cell viability were checked by the MTT (3- $(4,5$ dimethylthiazol-2-yl)-2,5-diphenyltetrazolium bromide) test as described elsewhere [27]. The THP-1 monocyte cell line and CEM lymphocytes were obtained from the American Type Culture Collection (Manassas, VA, USA).

\section{In vitro generation of microparticles and isolation from cell and plasma samples}

The release of MPs from CEM lymphocyte cells was induced by stimulation either with $A c t D$ alone at a concentration of 0.5 $\mu \mathrm{g} / \mathrm{mL}$ for 18 hours or with a combination of PHA $(5 \mu \mathrm{g} / \mathrm{mL})$ for 72 hours followed by PMA $(20 \mathrm{ng} / \mathrm{mL})$ and ActD $(0.5 \mu \mathrm{g} /$ $\mathrm{mL}$ ) for an additional 18-hour incubation period. THP-1 cells were treated with LPS $(15 \mu \mathrm{g} / \mathrm{mL})$ for 18 hours. Cell culture supernatants were centrifuged at $400 \mathrm{~g}$ for 5 minutes and then at $750 \mathrm{~g}$ for 15 minutes. Supernatants were harvested and centrifuged at $17,000 \mathrm{~g}$ for 30 minutes at $4^{\circ} \mathrm{C}$. Pellets were washed in HBSS, centrifuged for 30 minutes at $17,000 \mathrm{~g}$ at $4^{\circ} \mathrm{C}$, and finally resuspended in $500 \mu \mathrm{L}$ of HBSS. Synovial fluids were collected from RA, OA, microcristalline arthritis $(\mathrm{MC})$, and reactive arthritis (AR) patients on sodium citrate $(0.129 \mathrm{M})$ and centrifuged at room temperature for 15 minutes at 1,500 $g$ and then for 2 minutes at $13,000 \mathrm{~g}$. Supernatants were stored at $-80^{\circ} \mathrm{C}$ until use. In FLS-mediated activation experiments, MPs were isolated from patients by differential centrifugation as described for CEM lymphocyte and THP-1 cells. The last supernatant was used as a negative control to ensure that no remaining proteins could be responsible for the observed MP-mediated effects. Quantitative determinations of MPs were carried out using a prothrombinase assay after capture on immobilized annexin $\mathrm{V}$ as previously described. MP values are expressed as phosphatidylserine equivalents (PhtdSer Eq) by reference to a calibration curve constructed with synthetic phospholipid vesicles [28].

\section{Stimulation of cells for cytokine assays}

RA FLSs $\left(2 \times 10^{5}\right.$ cells $)$ were stimulated with $1 \mathrm{~mL}$ of complete medium (RPMI 1640 and M199/5\% dialyzed FCS) containing MPs. BAFF and SLPI secretion was assessed after 72hour MP treatment, whereas SLPI was measured after 48-hour MP treatment by a heterologous two-site sandwich enzymelinked immunosorbent assay (ELISA) in accordance with the instructions of the manufacturer (R\&D Systems, Lille, France). FLSs $\left(5 \times 10^{3}\right.$ cells) were grown to confluence in 96-well plates ( 7 to 10 days) and then stimulated with $200 \mu \mathrm{L}$ of serum-free RPMI 1640/M199 containing MPs. After a 20-hour incubation period, a heterologous two-site sandwich ELISA was used to estimate IL- 6 and IL- 8 release in culture supernatants. Negative controls consisted of cell culture medium and last supernatants obtained after MP isolation.

\section{Statistical analysis}

Results are expressed as mean \pm standard deviation. Statistical analysis was carried out using the Student test and by Wilcoxon non-parametric test to compare mean values between patient values or secreted molecules and released MPs in each experiment. All analyses were performed using SPSS 13.0 software (SPSS Inc., Chicago, IL, USA).

\section{Results}

\section{Isolation of microparticles}

MPs were isolated from synovial fluids obtained from patients with RA ( $n=7)$, OA $(n=5), M C(n=3)$, and AR $(n=5)$ by differential centrifugation. Characteristics of the patients are presented in Table 1. In this system, exosomes were eliminated after the first centrifugation at 17,000 g. Quantitative determinations of MPs were carried out using a prothrombinase assay after capture on immobilized annexin $V$ [28]. As shown in Figure 1a, synovial fluids from all patients tested contained MPs but their number was significantly higher in synovial fluids isolated from RA and MC patients (32 \pm 4 and $34 \pm$ $5 \mathrm{nM}$ PhtdSer Eq) compared with levels measured in synovial fluids obtained from OA and AR patients $(16 \pm 3$ and $18 \pm 3$ $\mathrm{nM}$ PhtdSer Eq, respectively). We also performed activation experiments with MPs isolated from CEM lymphocyte and THP-1 cells. CEM lymphocyte cells were treated with ActD $(0.5 \mu \mathrm{g} / \mathrm{mL})$ or with a combination of PHA $(5 \mu \mathrm{g} / \mathrm{mL})$, ActD $(0.5 \mu \mathrm{g} / \mathrm{mL})$, and PMA $(20 \mathrm{ng} / \mathrm{mL})$ as described in Materials and methods. THP-1 cells were stimulated with LPS from Salmonella abortus equi $(15 \mu \mathrm{g} / \mathrm{mL})$ and MPs were then isolated and quantified as described in Materials and methods. MP capture assay on annexin V showed that LPS treatment increased the number of MPs released from activated THP-1 cells (362 $\pm 76 \mathrm{nM}$ PhtdSer Eq) as compared with untreated THP-1 cells $(254 \pm 69$ nM PhtdSer Eq) $(P<0.05)$. MP capture on immobilized CD14 antibody indicated that stimulated THP-1 cells significantly released a higher proportion of MPs bearing CD14 (390 $\pm 75 \mathrm{nM}$ PhtdSer Eq) than unstimulated cells (63 $\pm 12 \mathrm{nM}$ PhtdSer Eq) (Figure 1b).

\section{Microparticles promoted the synthesis of B cell- activating factor by activated rheumatoid arthritis fibroblast-like synoviocytes}

To determine whether MPs are biologically active, we evaluated their ability to induce BAFF release by activated RA FLSs. In parallel, we also determined IL- 6 and IL- 8 production by MPtreated RA FLSs. FLSs were incubated for 20 and 72 hours with MPs isolated from RA synovial fluids, and IL-6, IL-8, and BAFF release was determined by ELISA. As shown in Figure $2 a, b$, incubation of FLSs with MPs at a concentration of $40 \mathrm{nM}$ PhtdSer Eq increased IL- 6 and IL-8 release by RA FLSs. IL-6 and IL-8 release reached $770 \pm 110$ and $1,150 \pm 130 \mathrm{pg} / \mathrm{mL}$, respectively, after 20 -hour incubation as compared with control medium (145 \pm 40 and $150 \pm 46 \mathrm{pg} / \mathrm{mL})$ and control supernatants $(300 \pm 30$ and $50 \pm 23 \mathrm{pg} / \mathrm{mL}$ ) (Figure 2a,b). 
Table 1

\begin{tabular}{|c|c|c|c|c|c|c|}
\hline Diagnosis & Patient & Gender & Age, years & Disease duration, years & Disease activity & Medications \\
\hline \multirow[t]{7}{*}{ RA } & 1 & Male & 75 & 10 & $\begin{array}{l}\text { DAS28 }=3.9 \\
\mathrm{CRP}=19 \mathrm{mg} / \mathrm{L}\end{array}$ & $\begin{array}{l}\text { Methotrexate } 15 \mathrm{mg} \\
\text { Prednisone } 5\end{array}$ \\
\hline & 2 & Female & 86 & 5 & $\begin{array}{l}\text { DAS28 }=4.7 \\
\mathrm{CRP}=12 \mathrm{mg} / \mathrm{L}\end{array}$ & $\begin{array}{l}\text { Methotrexate } 10 \mathrm{mg} \\
\text { Prednisone } 7 \mathrm{mg}\end{array}$ \\
\hline & 3 & Female & 79 & 20 & $\begin{array}{l}\text { DAS28 }=6 \\
\mathrm{CRP}=78 \mathrm{mg} / \mathrm{L}\end{array}$ & $\begin{array}{l}\text { Methotrexate } 15 \mathrm{mg} \\
\text { Prednisone } 10 \mathrm{mg}\end{array}$ \\
\hline & 4 & Female & 46 & 15 & $\begin{array}{l}\text { DAS28 }=4.1 \\
\mathrm{CRP}=17 \mathrm{mg} / \mathrm{L}\end{array}$ & $\begin{array}{l}\text { Methotrexate } 10 \mathrm{mg} \\
\text { Prednisone } 2 \mathrm{mg}\end{array}$ \\
\hline & 5 & Female & 55 & 6 & $\begin{array}{l}\text { DAS28 }=3.7 \\
\mathrm{CRP}=30 \mathrm{mg} / \mathrm{L}\end{array}$ & $\begin{array}{l}\text { Methotrexate } 17.5 \mathrm{mg} \\
\text { Prednisone } 5 \mathrm{mg}\end{array}$ \\
\hline & 6 & Male & 75 & 2 & $\begin{array}{l}\mathrm{DAS} 28=4.2 \\
\mathrm{CRP}=67 \mathrm{mg} / \mathrm{L}\end{array}$ & $\begin{array}{l}\text { Methotrexate } 10 \mathrm{mg} \\
\text { Prednisone } 7 \mathrm{mg}\end{array}$ \\
\hline & 7 & Male & 46 & 15 & $\begin{array}{l}\mathrm{DAS} 28=3.6 \\
\mathrm{CRP}=150 \mathrm{mg} / \mathrm{L}\end{array}$ & $\begin{array}{l}\text { Methotrexate } 10 \mathrm{mg} \\
\text { Prednisone } 5 \mathrm{mg} \\
\text { Infliximab ( } 3 \mathrm{mg} / \mathrm{kg})\end{array}$ \\
\hline \multirow[t]{5}{*}{ OA } & 1 & Male & 54 & 8 & $\mathrm{CRP}=4 \mathrm{mg} / \mathrm{L}$ & Paracetamol, NSAID \\
\hline & 2 & Female & 56 & 3 & $\mathrm{CRP}=6 \mathrm{mg} / \mathrm{L}$ & Paracetamol \\
\hline & 3 & Female & 46 & 5 & $\mathrm{CRP}=4 \mathrm{mg} / \mathrm{L}$ & Paracetamol, NSAID \\
\hline & 4 & Female & 65 & 7 & $\mathrm{CRP}=6 \mathrm{mg} / \mathrm{L}$ & Paracetamol \\
\hline & 5 & Male & 55 & 5 & $\mathrm{CRP}=4 \mathrm{mg} / \mathrm{L}$ & Paracetamol, Tramadol \\
\hline \multirow[t]{3}{*}{ MC } & 1 & Female & 55 & 3 & $\mathrm{CRP}=80 \mathrm{mg} / \mathrm{L}$ & Paracetamol, NSAID \\
\hline & 2 & Male & 50 & 1 & $\mathrm{CRP}=34 \mathrm{mg} / \mathrm{L}$ & Colchicine \\
\hline & 3 & Male & 74 & 1 & $\mathrm{CRP}=90 \mathrm{mg} / \mathrm{L}$ & NSAID \\
\hline \multirow[t]{5}{*}{ AR } & 1 & Male & 75 & 1 & $\mathrm{CRP}=54 \mathrm{mg} / \mathrm{L}$ & NSAID \\
\hline & 2 & Male & 30 & 2 & $\mathrm{CRP}=82 \mathrm{mg} / \mathrm{L}$ & NSAID \\
\hline & 3 & Male & 45 & 1 & $\mathrm{CRP}=20 \mathrm{mg} / \mathrm{L}$ & NSAID \\
\hline & 4 & Female & 20 & 1 & $\mathrm{CRP}=34 \mathrm{mg} / \mathrm{L}$ & Paracetamol \\
\hline & 5 & Male & 52 & 1 & $\mathrm{CRP}=25 \mathrm{mg} / \mathrm{L}$ & Paracetamol \\
\hline
\end{tabular}

Patients were diagnosed with rheumatoid arthritis based on American College of Rheumatology 1987 diagnostic criteria at least 3 months before study entry and have active disease. The diagnosis of microcristalline arthritis was based on clinical and laboratory features. All patients fulfilled the American College of Rheumatology criteria for acute gouty or pseudogout. All patients gave informed consent. AR, reactive arthritis; CRP, Creactive protein; DAS28, disease activity score using 28 joint counts; MC, microcristalline arthritis; NSAID, nonsteroidal anti-inflammatory drugs; $\mathrm{OA}$, osteoarthritis; RA, rheumatoid arthritis.

Equal concentrations of OA MPs had a comparable effect on IL-6 and IL-8 release.

We next determined whether MPs isolated from OA and RA synovial fluids might also play a role in BAFF release by FLSs. RA FLSs were incubated for 72 hours with MPs used at concentrations mentioned above, and BAFF release was evaluated in culture supernatants by ELISA. As shown in Figure 2c, BAFF secretion was increased in response to either OA or RA MPs after 72 hours and reached $320 \pm 76 \mathrm{pg} / \mathrm{mL}$ in response to RA MPs and $250 \pm 34 \mathrm{pg} / \mathrm{mL}$ in response to OA MPs as compared with control medium ( $30 \pm 9 \mathrm{pg} / \mathrm{mL}$ ) and control supernatants (70 \pm 12 and $50 \pm 21 \mathrm{pg} / \mathrm{mL}$, respectively). IFN$\gamma(180 \pm 23 \mathrm{pg} / \mathrm{mL})$ was used as a positive control. Taken together, these results indicate that MPs isolated from either OA and RA synovial fluids were able to activate IL-6, IL-8, and BAFF release by activated FLSs.

It was previously demonstrated that most MPs present in the synovial fluid of inflamed joints were leukocyte-derived MPs [23]. In the present study, we investigated the ability of MPs isolated from activated CEM lymphocyte and THP-1 cells to induce BAFF synthesis by activated RA FLSs.

IL-6 and IL-8 release was enhanced by MPs from ActD/PMA/ PHA-treated CEM lymphocytes (1,050 \pm 100 and 1,200 \pm $210 \mathrm{pg} / \mathrm{mL}$ for IL-6 and IL-8, respectively) when MPs were used at the concentration of $40 \mathrm{nM}$ PhtdSer Eq (Figure 3a,b). 

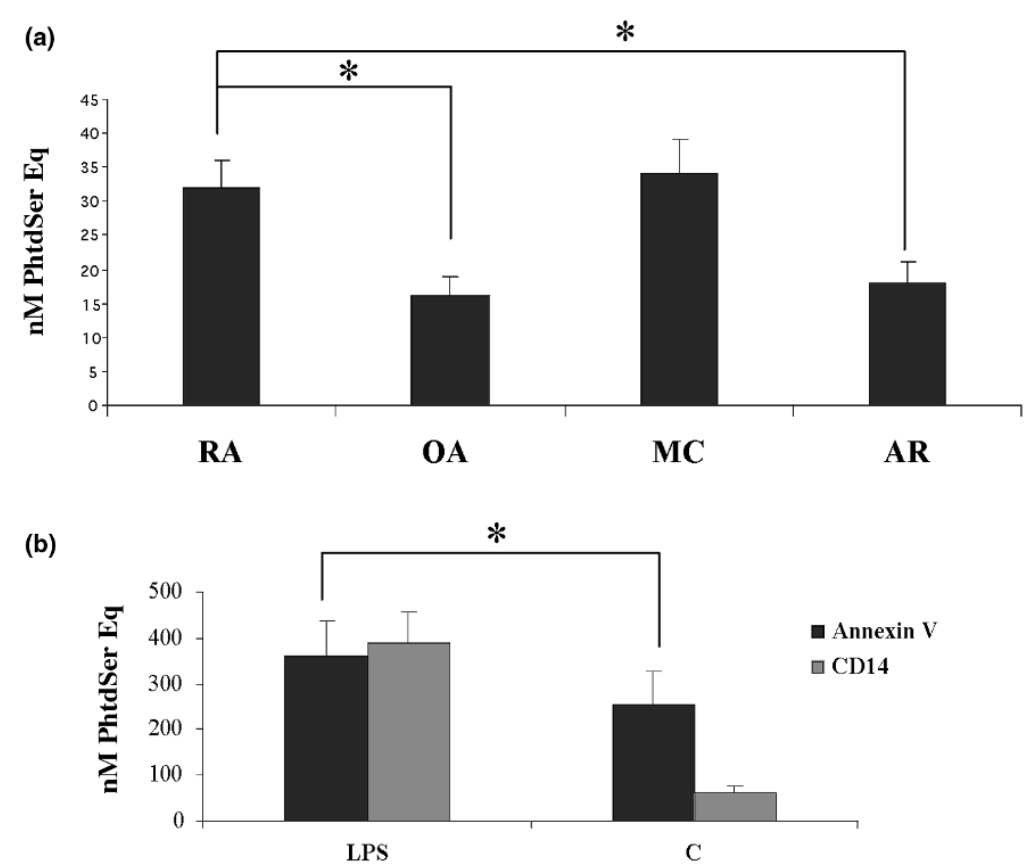

Microparticle (MP) assessment in synovial fluids from arthritic patients and cell supernatants. (a) Concentrations of MPs in synovial fluids from patients with rheumatoid arthritis (RA) $(n=7)$, osteoarthritis $(O A)(n=5)$, microcristalline arthritis $(M C)(n=3)$, and reactive arthritis (AR) ( $n=5)$ were determined by a solid-phase capture assay on immobilized annexin $\mathrm{V}$ by use of a prothrombinase assay (nM PhtdSer Eq). (b) Concentrations of MPs isolated from THP-1 cells stimulated with lipopolysaccharide (LPS) $(15 \mu \mathrm{g} / \mathrm{mL})$ for 18 hours were determined by a solid-phase capture assay on immobilized annexin $\mathrm{V}$ or on immobilized CD14 antibody by use of a prothrombinase assay (nM PhtdSer Eq). The control (C) corresponded to untreated cells. Data are expressed as the mean of triplicate samples \pm standard deviation and are representative of three independent experiments. ${ }^{\star} P<0.05$. PhtdSer Eq, phosphatidylserine equivalents.

Such MPs did not increase BAFF production at the same concentration. No induction of BAFF release was observed with a 10-fold increase in MP concentration $(P<0.01)$. IFN- $\gamma(170 \pm$ $25 \mathrm{pg} / \mathrm{mL}$ ) was used as a positive control of BAFF secretion (Figure 3c). Similar concentrations of MPs derived from ActDtreated CEM lymphocytes exhibited no significant effect on IL6 , IL-8, or BAFF release by activated RA FLSs (Figure 3c).

As monocytes/macrophages are considered major instigators of joint inflammation, we also analyzed whether MPs isolated from LPS-activated THP-1 cells first stimulate IL- 6 and IL-8 release by RA FLSs. As shown in Figure 4a,b, such MPs induced IL- 6 and IL- 8 release to a similar extent $(3,000 \pm 350$ $\mathrm{pg} / \mathrm{mL}$ ) in RA FLS supernatants. An induction of BAFF release was observed after incubation with MPs (40 nM PhtdSer Eq) derived from LPS-activated THP-1 cells (Figure 4c). BAFF release could not be observed in negative controls.

\section{Microparticles promoted the synthesis of thymic stroma lymphopoietin and secretory leukocyte protease inhibitor by activated rheumatoid arthritis fibroblast-like synoviocytes}

Having found that FLSs released BAFF in response to MP, we sought to determine whether MP-activated FLSs could amplify $B$-cell activation by stimulating dendritic cells to produce BAFF via TSLP. RA FLSs were stimulated with MPs derived from synovial fluids, CEM lymphocytes, and THP-1 cells at the concentration of $40 \mathrm{nM}$ PhtdSer Eq for 48 hours. As shown in Figure 5, RA FLSs released soluble TSLP protein after exposure to MPs. There were no significant differences between FLSs activated by MPs derived from synovial fluids, CEM lymphocytes, and THP-1 cells. SLPI is an antiprotease that is known to prevent BAFF-dependent class switching by inactivating nuclear factor-kappa-B (NF-kB). We detected SLPI in the supernantant of MP-activated RA FLSs 72 hours after activation. Thus, FLSs produce this homeostatic regulator of class switching after sensing MPs. Taken together, these results demonstrate that MPs derived either from synovial fluids from $\mathrm{RA}$ and $\mathrm{OA}$ patients or from leukocytes are able to induce BAFF, TSLP, and SLPI release by activated RA FLSs and could participate in cell-cell interactions leading to the proinflammatory response of FLSs as well as in their implication in the B-cell autoimmune response.

\section{Discussion}

BAFF is a cytokine that plays a pivotal role in B-cell survival, differentiation, and activation. We and others recently demonstrated that resident cells of the synovial membrane synthesize and release BAFF in response to stimulation of innate immune receptors such as integrin $\alpha 5 \beta_{1}$ and IFN- $\gamma$ receptors $[20,21]$. Beside this established key BAFF, other molecules might influence directly or indirectly B cells such as TSLP and SLPI. 
Figure 2
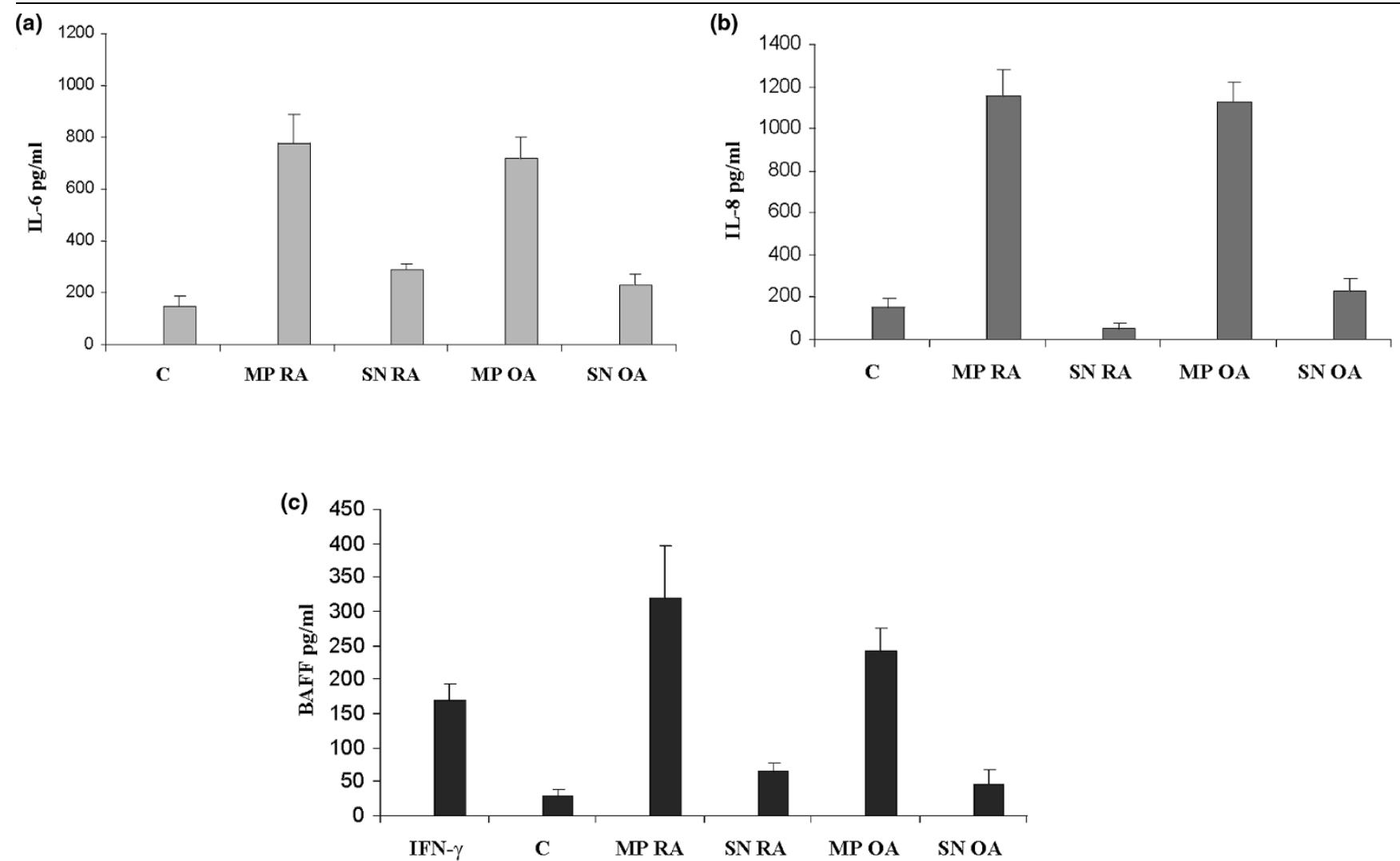

Induction of interleukin (IL)-6, IL-8, and B cell-activating factor (BAFF) synthesis by microparticles (MPs) isolated from synovial fluids. Rheumatoid arthritis (RA) fibroblast-like synoviocytes were stimulated with $40 \mathrm{nM}$ phosphatidylserine equivalents of MPs isolated from synovial fluids of osteoarthritis (OA) and RA patients for 24 and 72 hours. IL-6 (a), IL-8 (b), and BAFF (c) release was determined by enzyme-linked immunosorbent assay. Data are expressed as the mean of triplicate samples \pm standard deviation and are representative of three independent experiments. $\mathrm{C}$, control medium; IFN- $\gamma$, interferon-gamma; SN, control supernatants.

Direct evidence of the capacity of these factors to promote Bcell activation was demonstrated following TLR activation of oral epithelial cells [22].

As an increasing body of evidence suggested that MPs have potent proinflammatory activities and are potentially important mediators of inflammatory and autoimmune diseases [29-33], we have investigated in this study the role of MPs on BAFF, TSLP, and SLPI secretion by FLSs isolated from RA patients. MPs are produced during cell death but they may also arise during cell activation. They can be produced by virtually all cell types, but in contrast to MPs isolated from blood, MPs isolated from synovial fluids from RA patients are derived mainly from inflammatory and immune cells [23].

We first evaluated MP levels in synovial fluids obtained from patients with RA (7), OA (5), MC (3), and AR (5). All synovial fluids contained MPs although their levels seemed to be higher in RA and MC synovial fluids. These results are in accordance with observations indicating that the number of MPs is increased during inflammatory states in vivo [23].
As Distler and colleagues [16] demonstrated that MPs serve as important triggering elements to promote cytokine, chemokine, and MMP release from RA synovial fibroblasts, we then explored the role of RA and OA synovial fluid-derived MPs in inducing BAFF synthesis by activated FLSs. In the present study, we demonstrated a new mechanism by which FLSs could contribute to the adaptative autoimmune response. We showed that MPs, which are produced in synovial fluids during RA and OA, are potent stimuli of BAFF synthesis in a similar degree to IFN- $\gamma$, which is used as positive control. To our knowledge, this is the first time that BAFF induction by MPs has been demonstrated. This effect was observed with both RA and OA MPs, suggesting that MPs isolated from joints of patients with degenerative joint diseases such as OA have the same effect as MPs present in the joints of patients with RA and therefore that this action is not disease-dependent. The main difference regarding the assessed effect concerns the levels of MPs, which are much lower in synovial fluids of OA than of RA. However, it can be speculated that other types of cytokines and other functional effects of MPs which were not assessed in the present study might be different. It must be noted that, in contrast to other studies, this work was per- 
Figure 3
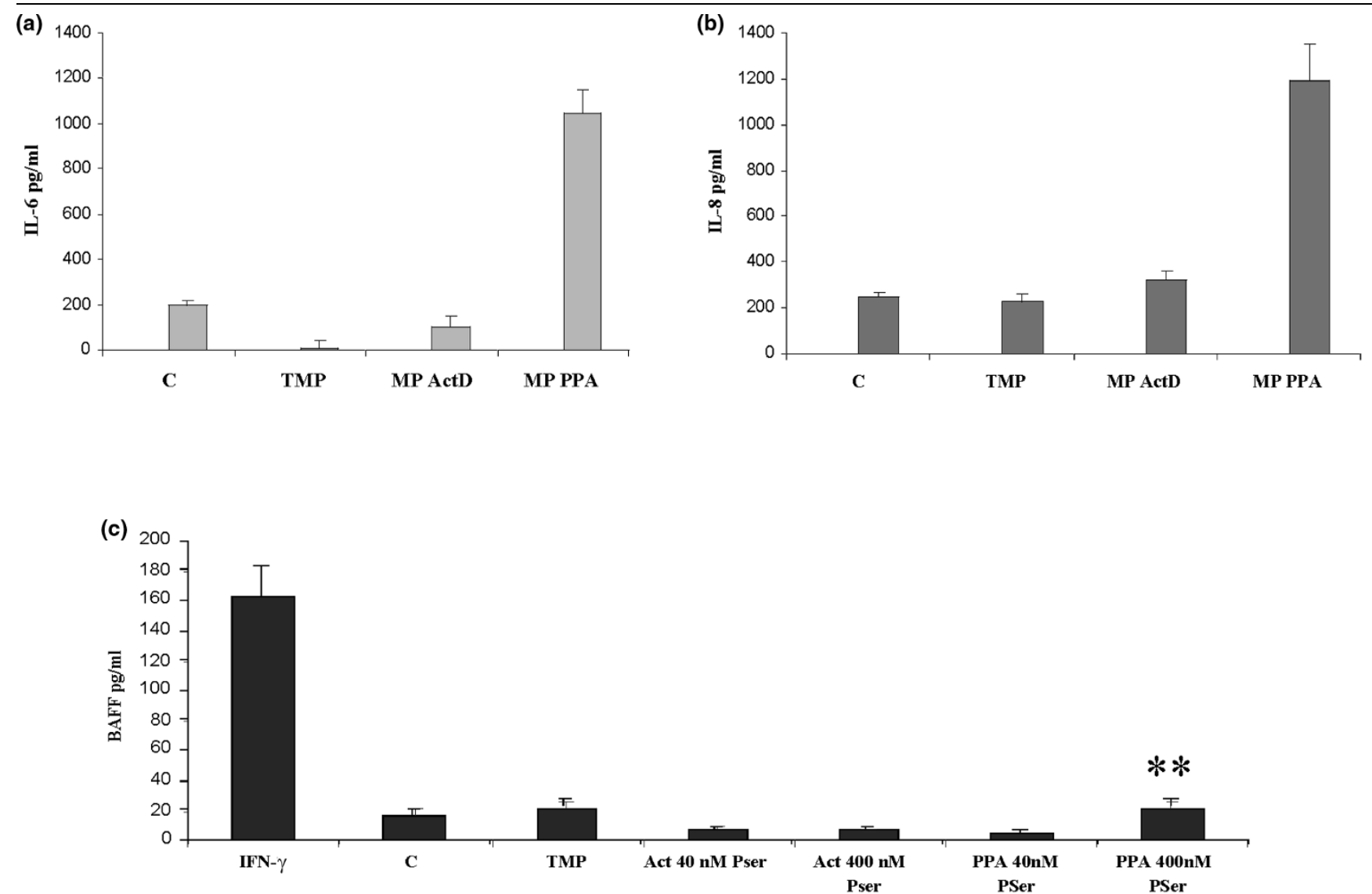

Induction of interleukin (IL)-6, IL-8, and B cell-activating factor (BAFF) synthesis by microparticles (MPs) isolated from CEM lymphocytes. Rheumatoid arthritis fibroblast-like synoviocytes were stimulated with 40 and $400 \mathrm{nM}$ phosphatidylserine equivalents of MPs isolated from CEM lymphocytes treated either with actinomycin D (ActD) alone $(0.5 \mu \mathrm{g} / \mathrm{mL})$ for 18 hours or with a combination of PHA, PMA and Adt-D (PPA) (phytohemagglutinin) $(5 \mu \mathrm{g} / \mathrm{mL})$ for 72 hours followed by ActD $(0.5 \mu \mathrm{g} / \mathrm{mL})$ and phorbolmyristate acetate $(20 \mathrm{ng} / \mathrm{mL})$ for an additional 18-hour incubation period. Culture supernatants were harvested 24 hours after stimulation for IL-6 (a) and IL-8 (b) determination and 72 hours after stimulation for BAFF evaluation (c) by enzyme-linked immunosorbent assay. Lipopolysaccharide (IL-6 and IL-8) and interferon-gamma (IFN- $\gamma$ ) (BAFF) stimulation was used as a positive control. Data are expressed as the mean of triplicate samples \pm standard deviation and are representative of three independent experiments. ${ }^{\star \star} P<$ 0.01. Act, actinomycin; C, control medium; Pser, phosphatidylserine; TMP, control Hanks' balanced saline solution.

formed with purified MPs free of exosomes, which are preformed vesicles of endosomal origin which are stored intracellularly in multivesicular bodies and released by exocytosis. Exosomes, which are investigated mainly in the regulation of immune responses, do not expose phosphatidyserine, they share a common set of membrane molecules like tetraspanins, and they harbor unique subsets of proteins linked to cell type-associated functions [34,35]. Results suggest that MPs could contribute to the interplay between FLSs and B cells through BAFF synthesis. This induction of BAFF might also contribute to the increased proliferation of FLSs in RA, which might also be related to the autocrine effect of BAFF on FLSs. Indeed, FLSs not only secrete BAFF, they also bear BAFF receptors [36]. Berckmans and colleagues [15,37] found that, in patients with RA, most of the MPs present in the synovial fluid are produced by monocytes/macrophages, $\mathrm{T}$ cells, and granulocytes. MPs deriving from B cells, platelets, and erythrocytes are present only in low numbers.
To gain further information about the parental cells possibly involved in MP-mediated BAFF synthesis, we explored the effect of MPs isolated from CEM lymphocyte and THP-1 cells activated under various conditions. As previously shown by studies performed with LPS-treated U937 cells [38], THP-1 cell-derived MPs exhibit strong proinflammatory activities. Moreover, they were able to induce BAFF release by activated FLSs. In view of the abundance of these cells in the synovial cavity in RA, our results suggest that macrophages could serve as important triggering elements in promoting the inflammatory response and cooperation with $B$ cells through the release of MPs. In contrast, we observed that MPs derived from activated CEM lymphocytes, which are inducers of IL- 6 and $\mathrm{IL}-8$ release, did not promote BAFF synthesis. BAFF release was not observed even with a 10-fold increase in MP concentration. T cells also occur abundantly in synovium and synovial fluids; nevertheless, our data demonstrate that MPs eventually produced by activated lymphocytes $\mathrm{T}$ in vivo cannot 
Figure 4

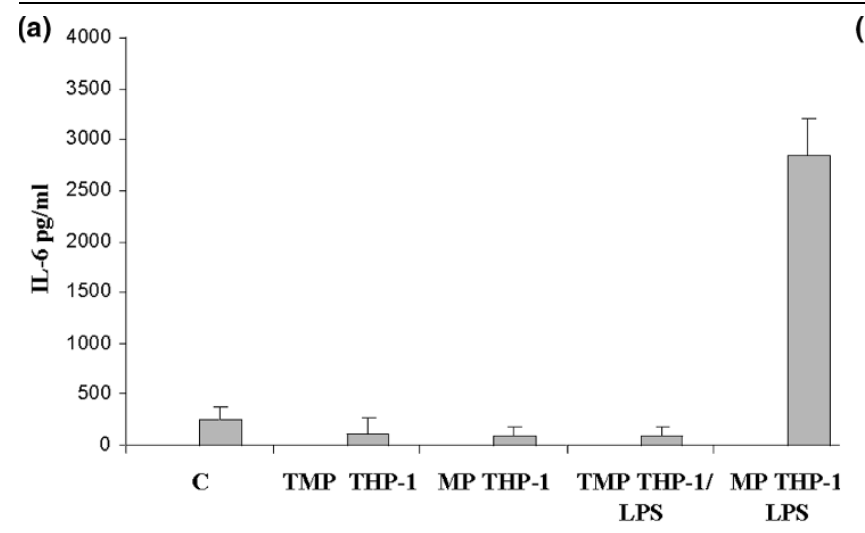

(b)

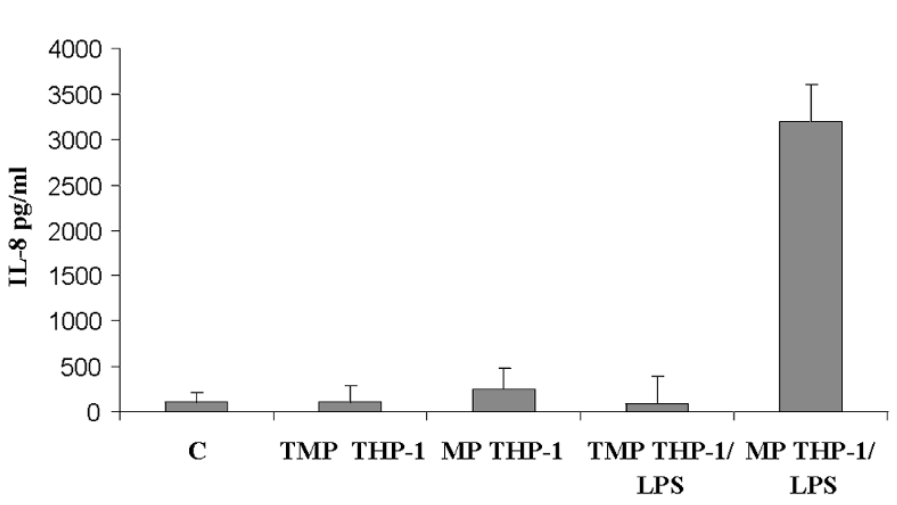

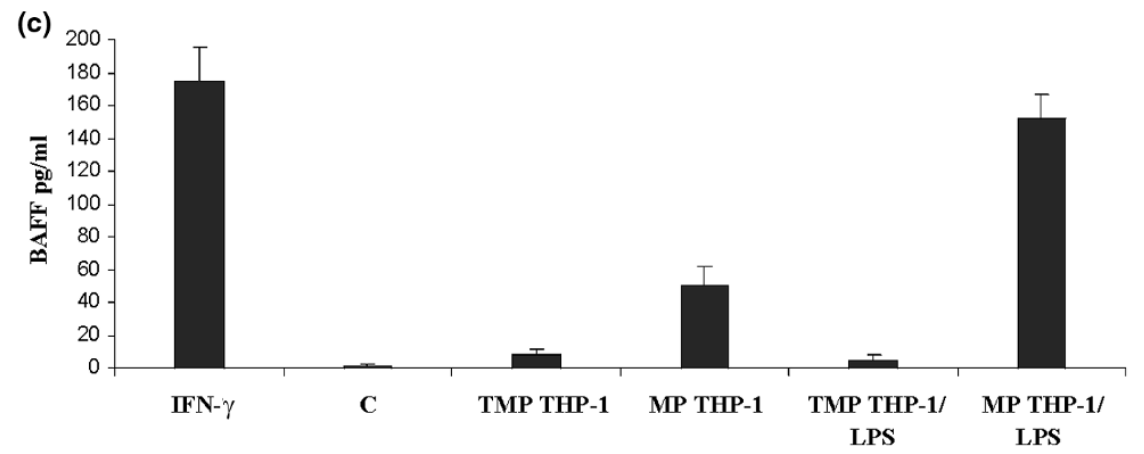

Induction of interleukin (IL)-6, IL-8, and B cell-activating factor (BAFF) synthesis by microparticles (MPs) isolated from lipopolysaccharide (LPS)-activated THP-1 cells. THP-1 cells were treated with LPS $(15 \mu \mathrm{g} / \mathrm{mL})$ for 18 hours, and MPs were isolated as described in Materials and methods. Rheumatoid arthritis (RA) FLSs were stimulated with $40 \mathrm{nM}$ phosphatidylserine equivalents of MPs isolated either from THP-1 cells (MP THP-1) or from LPS-activated THP-1 cells (MP THP-1 LPS). Culture supernatants were harvested 24 hours after stimulation for IL-6 (a) and IL-8 (b) determination and 72 hours after stimulation for BAFF secretion (c) by enzyme-linked immunosorbent assay. LPS (IL-6 and IL-8) and interferon-gamma (IFN$\gamma$ ) (BAFF) were used as positive controls. Data are expressed as the mean of triplicate samples \pm standard deviation and are representative of three independent experiments. C, control medium; TMP, control Hanks' balanced saline solution.

be considered key contributors in the induction of BAFF. We cannot rule out that MPs released by other cells present in the synovial cavity such as FLSs could interfere in this process. In fact, we have performed some preliminary experiments with MPs isolated from LPS-activated FLSs and have observed that these MPs act in an autocrine pathway and induce IL-6 release by activated FLSs (data not shown).

We reported also that MPs isolated from synovial fluids, CEM lymphocytes, or THP-1 cells were strong inducers of TSLP. TSLP is an IL-7-like cytokine that stimulates dendritic cells to produce more BAFF and constitutes a Th2-independent pathway for antibody production. It was demonstrated that epithelial cells lining tonsillar crypts released AID (activation-induced cytidine deaminase)-inducing factors, including BAFF, IL-10, and TSLP, after sensing viral RNA through TLR3 [22]. The resultant class switching caused the production of broadly $\lg \mathrm{G}$ and $\lg \mathrm{A}$ antibodies, including antibodies to self antigens. RA FLSs also release TSLP in response to LPS and poly I:C, and this effect is downregulated by IFN- $\gamma$ and dexamethasone
[39]. Our findings indicate that, like LPS and poly I:C, MPs could indirectly participate in B-cell activation by activating dendritic cells through TSLP release by RA FLSs and may be involved in the physiopathology of inflammatory arthritis.

However, we also showed that RA FLSs activated with MPs isolated from synovial fluids, CEM lymphocytes, or THP-1 cells release SLPI. SLPI was originally identified as a protein synthesized by macrophages which antagonized LPS activation of NF- $\kappa B$. In B lymphocytes, SLPI inhibits class switching by interfering with NF- $\kappa \mathrm{B}$-dependent pathways and with the upregulation of AID induced by BAFF and viral RNA. As SLPI is released at a later time point, it may restrain the intrasynovial production of potentially pathogenic $\lg G$ antibodies. This needs to be demonstrated.

\section{Conclusions}

Our studies indicated that MPs are potent inducers of proinflammatory factors as well as B-cell survival and promote the release of activation factors such as BAFF or TSLP by RA 

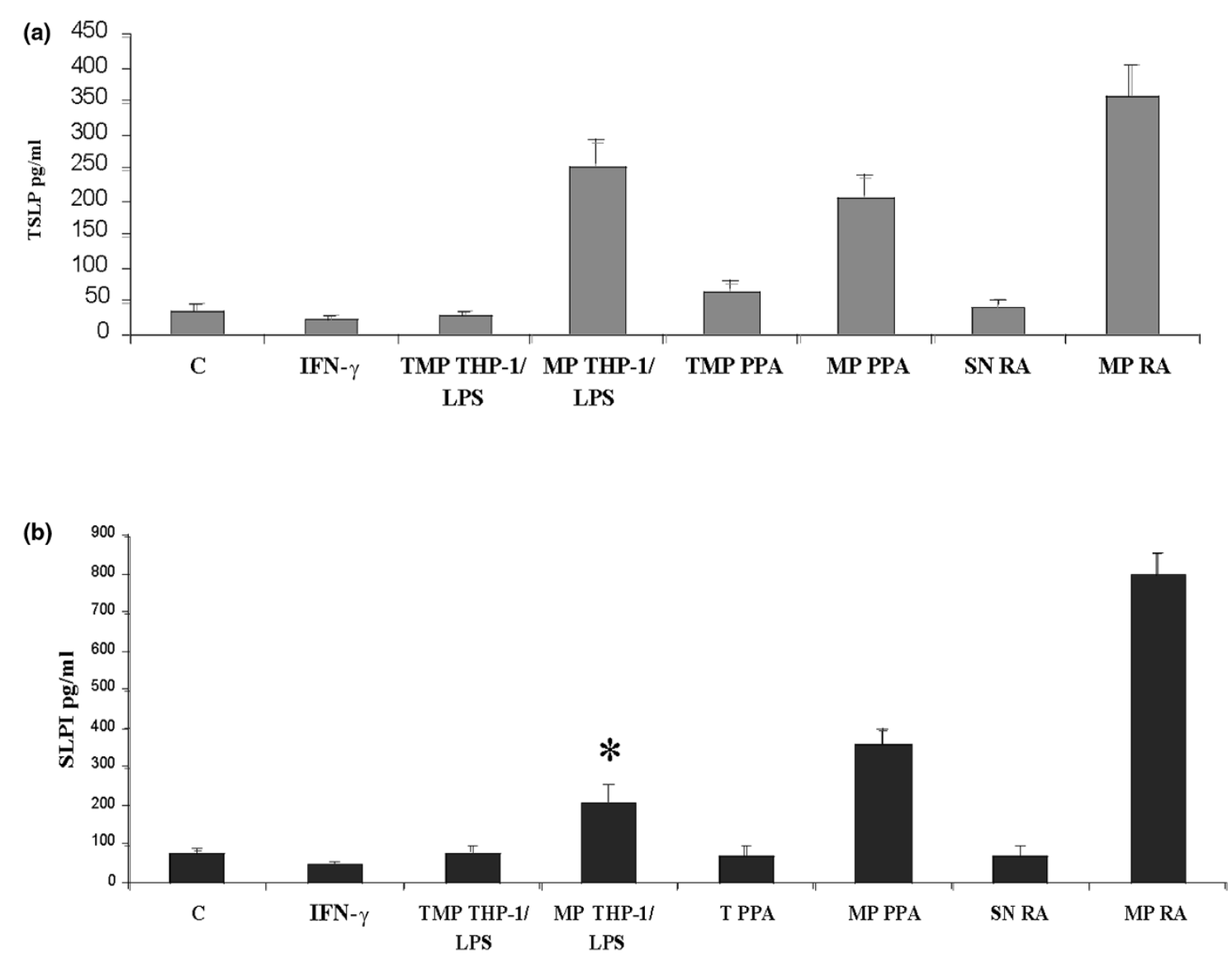

Induction of thymic stroma lymphopoietin (TSLP) and secretory leukocyte protease inhibitor (SLPI) synthesis by activated rheumatoid arthritis (RA) fibroblast-like synoviocytes (FLSs). TSLP (a) and SLPI (b) release was determined by enzyme-linked immunosorbent assay in supernatants of RA FLSs stimulated 48 hours (TSLP) and 72 hours (SLPI) with microparticles (MPs) (40 nM phosphatidylserine equivalents) isolated from RA synovial fluids, lipopolysaccharide (LPS)-treated THP-1 cells, and PHA, PMA and Adt-D (PPA)-treated CCRF-CEM cells. Data are expressed as the mean of triplicate samples \pm standard deviation and are representative of three independent experiments. ${ }^{\star} P<0.05$. C, control medium; IFN- $\gamma$, interferongamma; SN, control supernatants; TMP, control Hanks' balanced saline solution.

FLSs. This cellular response is regulated by SLPI release. Thus, MPs might play a fundamental role and behave as sensors in the control of humoral B-cell responses in RA synovium.

\section{Competing interests}

The authors declare that they have no competing interests.

\section{Authors' contributions}

GA participated in designing and performing all experiments and in drafting the manuscript. LM participated in designing and performing all experiments and in drafting the manuscript and collected patient samples. FT-O supervised the characterization of MPs and the production of cell-derived MPs of various origins and edited the manuscript. FZ performed cell culture and MP quantitative determinations in patients and cell supernatants. IL performed cell culture and MP quantitative determinations in patients and cell supernatants. JS conceived the study. J-MF assisted in designing the study. J-EG edited the manuscript. DW conceived the study and drafted and edited the manuscript. All authors read and approved the final manuscript.

\section{Acknowledgements}

The work of DW was supported by grants from Bristol-Myers Squibb Company (Princeton, NJ, USA), Roche (Basel, Switzerland), Pfizer Inc (New York, NY, USA), the Courtin Foundation, and CAMPLP.

\section{References}

1. Firestein GS: Evolving concept of rheumatoid arthritis. Nature 2003, 423:356-361.

2. Muller-Ladner U, Ospelt C, Gay S, Distler O, Pap T: Cells of the synovium in rheumatoid arthritis synovial fibroblasts. Arthritis Res Ther 2007, 9:223-230.

3. Al-Okla S, Chatenay-Rivauday C, Klein JP, Wachsmann D: Involvement of alpha5beta1 integrins in interleukin 8 production induced by oral viridans streptococcal protein I/IIf in cultured endothelial cells. Cell Microbiol 1999, 1:157-168.

4. Zeisel BM, Druet V, Wachsmann D, Sibilia J: MMP-3 expression and release by rhumatoid arthritis fibroblast-like synoviocytes induced with a bacterial ligand of integrin $\alpha 5 \beta R$. Arthritis Res Ther 2005, 7:R118. 
5. Morel O, Toti F, Bakouboula B, Grunebaum L, Freyssinet JM: Procoagulant microparticles: 'criminal partners' in atherothrombosis and deleterious cellular exchanges. Pathophysiol Haemost Thromb 2006, 35:15-22.

6. Martinez MC, Kunzelmann C, Freyssinet JM: Plasma membrane remodelling and cell stimulation. Med Sci (Paris) 2004, 20:189-195.

7. Denzer K, van Eijk M, Kleijmeer MJ, Jakobson E, de Groot C, Geuze $\mathrm{HJ}$ : Follicular dendritic cells carry MHC class II-expressing microvesicles at their surface. J Immunol 2000, 165:1259-1265.

8. Morel O, Toti F, Hugel B, Freyssinet JM: Cellular microparticles: a disseminated storage pool of bioactive vascular effectors. Curr Opin Hematol 2004, 11:156-164.

9. Morel O, Toti F, Hugel B, Bakouboula B, Camoin-Jau L, DignatGeorge F, Freyssinet JM: Procoagulant microparticles: disrupting the vascular homeostasis equation? Arterioscler Thromb Vasc Biol 2006, 26:2594-2604.

10. Ardoin SP, Shanahan JC, Pisetsky DS: The role of microparticles in inflammation and thrombosis. Scand J Immunol 2007, 66:159-165.

11. Andoh A, Tsujikawa T, Hata K, Araki Y, Kitoh K, Sasaki M, Yoshida T, Fujiyama Y: Elevated circulating platelet-derived microparticles in patients with active inflammatory bowel disease. $\mathrm{Am} \mathrm{J}$ Gastroentero/ 2005, 100:2042-2048.

12. Nieuwland R, Berckmans RJ, McGregor S, Böing AN, Romijn FP, Westendorp RG, Hack CE, Sturk A: Cellular origin and procoagulant properties of microparticles in meningococcal sepsis. Blood 2000, 95:930-935.

13. Morel N, Morel O, Delabranche X, Jesel L, Sztark F, Dabadie P, Freyssinet JM, Toti F: Microparticles during sepsis and trauma. A link between inflammation and thrombotic processes. Ann $\mathrm{Fr}$ Anesth Reanim 2006, 25:955-966.

14. Minagar A, Jy W, Jimenez JJ, Sheremata WA, Mauro LM, Mao WW, Horstman LL, Ahn YS: Elevated plasma endothelial microparticles in multiple sclerosis. Neurology 2001, 56:1319-1324.

15. Berckmans RJ, Nieuwland R, Kraan MC, Schaap MC, Pots D, Smeets TJ, Sturk A, Tak PP: Synovial microparticles from arthritic patients modulate chemokine and cytokine release by synoviocytes. Arthritis Res Ther 2005, 7:R536-R544.

16. Distler JHW, Jüngel A, Huber LC, Seemayer CA, Reich CF III, Gay RE, Michel BA, Fontana A, Gay S, Pisetsky DS, Distler O: The induction of matrix mettaloproteinase and cytokine expression in synovial fibroblast stimulated with immune cell microparticles. Proc Natl Acad Sci USA 2005, 102:2892-2897.

17. Burger JA, Zvaifler NJ, Tsukada N, Firestein GS, Kipps TJ: Fibroblast-like synoviocytes support B-cell pseudoperiempolesis via a stromal cell-derived factor-1 and CD106 (VCAM-1)-dependent mechanism. J Clin Invest 2001, 107:305-315.

18. Shi K, Hayashida K, Kaneko M, Hashimoto J, Tomita T, Lipsky PE, Yoshikawa $\mathrm{H}$, Ochi $\mathrm{T}$ : Lymphoid chemokine B-cell attracting chemokine-1 (CXCL13) is expressed in germinal center of ectopic lymphoid follicles within the synovium of chronic arthritis patients. J Immunol 2001, 166:650-655.

19. Weyand CM, Goronzy JJ: Ectopic germinal center formation in rheumatoid synovitis. Ann NY Acad Sci 2003, 987:140-149.

20. Ohata J, Zvaifler NJ, Nishio M, Boyle DL, Kalled SL, Carson DA, Kipps TJ: Fibroblast-like synoviocytes of mesenchymal origin express functional B cell-activating factor of the TNF family in response to proinflammatory cytokines. J Immunol 2005, 174:864-870.

21. Alsaleh G, Messer L, Semaan N, Boulanger N, Gottenberg JE, Sibilia J, Wachsmann D: BAFF synthesis by rheumatoid synoviocytes is positively controlled by alpha5beta 1 integrin stimulation and is negatively regulated by tumor necrosis factor alpha and Toll-like receptor ligands. Arthritis Rheum 2007, 56:3202-3214

22. Xu W, He B, Chiu A, Chadburn A, Shan M, Buldys M, Ding A, Knowles DM, Santini PA, Cerutti A: Epithelial cells trigger frontline immunoglobulin class switching through a pathway regulated by the inhibitor SLPI. Nat Immuno/ 2007, 8:294-303.

23. Jorg H, Distler W, Huber LC, Gay S, Distler O, Pisetsky DS: Microparticles as mediators of cellular cross-talk in inflammatory disease. Autoimmunity 2006, 39:683-690.

24. Dechanet J, Taupin JL, Chomarat $P$, Rissoan MC, Moreau JF, Banchereau J, Miossec P. Interleukin-4 but not interleukin-10 inhibits the production of leukemia inhibitory factor by rheu- matoid synovium and synoviocytes. Eur J Immunol 1994, 24:3222-3228.

25. Frank C, Arnett FC, Edworthy SM, Bloch DA, McShane DJ, Fries JF, Cooper NS, Healey LA, Kaplan SR, Liang MH, Luthra HS, Medsger TA Jr, Mitchell DM, Neustadt DH, Pinals RS, Schaller JG, Sharp JT, Wilder RL, Hunder GG: The American Rheumatism Association 1987 revised criteria for the classification of rheumatoid arthritis. Arthritis Rheum 1988, 31:315-324.

26. Neff L, Zeisel M, Sibilia J, Scholler-Guinard M, Klein JP, Wachsmann D: NF-kappaB and the MAP kinases/AP-1 pathways are both involved in interleukin- 6 and interleukin-8 expression in fibroblast-like synoviocytes stimulated by protein I/II, a modulin from oral streptococci. Cell Microbiol 2001, 3:703-712.

27. Mosmann T: Rapid colorimetric assay for cellular growth and survival: application to proliferation and cytotoxicity assays. $J$ Immunol Methods 1983, 65:55-63.

28. Jy W, Horstman LL, Jimenez JJ, Ahn YS, Biró E, Nieuwland R, Sturk A, Dignat-George F, Sabatier F, Camoin-Jau L, Sampol J, Hugel B, Zobairi F, Freyssinet JM, Nomura S, Shet AS, Key NS, Hebbel RP: Measuring circulating cell-derived microparticles. J Thromb Haemost 2004, 2:1842-1851.

29. Jüngel A, Distler O, Schulze-Horsel U, Huber LC, Ha HR, Simmen B, Kalden JR, Pisetsky DS, Gay S, Distler JH: Microparticles stimulate the synthesis of prostaglandin $\mathrm{E}(2)$ via induction of cyclooxygenase 2 and microsomal prostaglandin E synthase 1. Arthritis Rheum 2007, 56:3564-3574.

30. Morel O, Morel N, Hugel B, Jesel L, Vinzio S, Goichot B, Bakouboula B, Grunebaum L, Freyssinet JM, Toti F: The significance of circulating microparticles in physiology, inflammatory and thrombotic diseases. Rev Med Interne 2005, 26:791-801.

31. Mause SF, von Hundelshausen P, Zernecke A, Koenen RR, Weber C: Platelet microparticles: a transcellular delivery system for RANTES promoting monocyte recruitment on endothelium. Arterioscler Thromb Vasc Biol 2005, 25:1512-1518.

32. Gasser O, Schifferli JA: Activated polymorphonuclear neutrophils disseminate anti-inflammatory microparticles by ectocytosis. Blood 2004, 104:2543-2548.

33. Van Wijk MJ, van Bavel E, Sturk A, Nieuwland R: Microparticles in cardiovascular diseases. Cardiovasc Res 2003, 59:277-287.

34. Keller S, Sanderson MP, Stoeck A, Altevogt P: Exosomes: from biogenesis and secretion to biological function. Immunol Lett 2006, 107:102-108.

35. Johnstone RM: Exosomes biological significance: a concise review. Blood Cells Mol Dis 2006, 36:315-321.

36. Nagatani K, Itoh K, Nakajima K, Kuroki H, Katsuragawa $Y$, Mochizuki M, Aotsuka S, Mimori A: Rheumatoid arthritis fibroblast-like synoviocytes express BCMA and are stimulated by APRIL. Arthritis Rheum 2007, 56:3554-3563.

37. Berckmans RJ, Nieuwland R, Tak PP, Boing AN, Romijin FP, Kraan MC, Breedveld FC, Hack CE, Sturk A: Cell-derived microparticles in synovial fluid from inflamed arthritic joints support coagulation exclusively via a factor VII-dependent mechanism. Arthritis Rheum 2002, 46:2857-2866.

38. Xie GL, Nomura S, Fukuhara S: Annexin V expression and membrane vesiculation during activation of leukemic cell lines. Haemostasis 1997, 27:259-268.

39. Ozawa T, Koyama K, Ando T, Ohnuma Y, Hatsushika K, Ohba T, Sugiyama H, Hamada Y, Ogawa H, Okumura K, Nakao A: Thymic stromal lymphopoietin secretion of synovial fibroblasts is positively and negatively regulated by Toll-like receptors/nuclear factor-kappaB pathway and interferon-gamma/dexamethasone. Mod Rheumato/ 2007, 17:459-463. 